\title{
An Incrase In Skills Concluded Text Reading Trough Model Cooperative Integreted Reading and Composition
}

\section{Zulaekha}

SD Negeri Kalirejo 03

zulaekhalaura@gmail.com

\section{Article History}

accepted 14/11/2020

approved 21/11/2020

published 26/11/2020

\begin{abstract}
The purpose of this research to increase reading text that concluded with the reading integreted learning cooperation and composition in charge subject of Indonesian language in primary school class I. research is by research the act of class (PTK) as much as the, with every consisting of planning, observation and reflection. The meeting test done by post, 1 in students completed 2 reached $90 \%$ this shows that cooperation learning model reading integreted and composition can improve learning outcomes especially charge students subject of Indonesian language class 1 at SDN Kalirejo 03
\end{abstract}

Keywords: Skills concluded,cooperative integreted reading and composition,indonesian language

\begin{abstract}
Abstrak
Tujuan penelitian ini untuk peningkatan ketrampilan menyimpulkan teks bacaan dengan model pembelajaran Cooperative Integreted Reading and Composition(CIRC) pada mupel Bahasa Indonesia disekolah dasar kelas 1. Penelitian yang dilakukan adalah penelitian tindakan kelas(PTK) sebanyak dua siklus dengan setiap siklusnya terdiri dari perencanaan, pelaksanaan, pengamatan, dan refleksi. Setiap pertemuan dilakukan dengan post tes,di siklus 1 peserta didik yang tuntas mencapai $60 \%$ sedangkan pada siklus II yang tuntas mencapai $90 \%$. Hal ini menunjukkan bahwa dengan model pembelajaran Cooperative Integreted Reading and Composition dapat meningkatkan hasil belajar peserta didik khususnya pada muatan pelajaran Bahasa Indonesia kelas I di SD Negeri Kalirejo 03.
\end{abstract}

Kata kunci: Ketrampilan menyimpulkan, cooperative integreted reading and composition, bahasa indonesia

Social, Humanities, and Education Studies (SHEs): Conference Series https://jurnal.uns.ac.id/shes 


\section{PENDAHULUAN}

Sebagian besar pola pembelajaran Bahasa Indonesia masih bersifat transmisif, yaitu: guru memberikan konsep-konsep yang terdapat dalam buku pelajaran secara langsung pada peserta didik dan siswa secara pasif menyerap pengetahuan tersebut (Trianto, 2011:18). Meskipun, metode pembelajaran dengan kerja kelompok sudah mulai diterapkan. Namun, pembelajaran dengan kerja kelompok yang masih bersifat tradisional, yakni: masing-masing kelompok memilih sendiri anggota-anggota kelompoknya kurang membantu dalam meningkatkan hasil belajar siswa. Strategi dan metode pembelajaran yang digunakan selama ini sangat berpengaruh terhadap hasil belajar siswa. Cara penyampaian materi yang tidak menarik dan monoton menyebabkan siswa tidak bisa mengikuti pembelajaran dengan baik sehingga berpengaruh pada ketercapaian Kriteria Ketuntasan Minimal (KKM).

Menurut Brunner dalam Sugandi (2007:36) ada empat hal pokok penting yang perlu diperhatikan yaitu peranan pengalaman sruktur pengetahuan, kesiapan mempelajarai sesuatu, intuisi dan cara membangkitkan motivasi belajar, Guru dituntut untuk bisa membawa peserta didik kedalam dunia yang menyenangkan didalam pembelajaran. Peserta didik yang merasa nyaman dan senang, maka akan berani untuk aktif dan akan mempunyai motifasi lebih untuk terus belajar, biasanya akan mendapatkan hasil belajar yang baik. Karena dengan model pembelajaran yang pas dengan karakteristik siswa maka hasilnya akan lebih tercapai.

Pada muatan Bahasa indonesia ini yang cocok dengan model pembelajaran cooperative Integreted Reading and Composition . karena di bahasa indonesia ada 4 aspek yaitu mendengarkan,berbicara, membaca dan menulis. Fungsi membaca atau manfaat membaca menurut Jordan E (2008) yaitu membaca menambah kosa kata dan pengetahuan akan tata bahasa dan tata kalimat, dan memicu imajinasi karena buku atau bacaan yang baik akan mengajak kita membayangkan dunia beserta isinya. Hal itu terjadi pula dalam proses pembelajaran di kelas 1 SDN Kalirejo 03. Dimana rendahnya keterampilan menyimpulkan teks bacaan dalam muatan pelajaran Bahasa Indonesia. Penyebabnya antara lain karena metode yang digunakan masih konvensional dengan menggunakan metode hafalan dan ceramah. Hal tersebut menyebabkan kegiatan pembelajaran berjalan pasif. Fakta ini menunjukkan bahwa kemampuan siswa dalam memahami serta hasil serta keterampilan belajar yang masih rendah.

Kondisi seperti ini ditunjukkan dengan nilai prestasi siswa yang berada dibawah KKM ( Kriteria Ketuntasan Minimal ). Dapat diketahui dari 10 orang siswa kelas 1 SDN Kalirejo 03 hanya 3 siswa ( $30 \%$ )yang mendapat nila diatas KKM (70). Hal ini juga diikuti dengan motivasi siswa yang masih rendah dalam pembelajaran Bahasa Indonesia.

Terampil sendiri bermakna cakap atau mampu dan cekatan, sebagai kata dasar dari kata keterampilan. Sedangkan keterampilan, bermakna kecakapan atau kemampuan dan kecekatan. Keterampilan berbahasa adalah kemampuan dan kecekatan menggunakan bahasa yang meliputi membaca, berbicara, menulis, dan menyimak. Keterampilan berbahasa dapat dibagi menjadi dua, yakni secara lisan dan tulis. Dari kelompok keterampilan berbahasa secara lisan, meliputi menyimak dan berbicara. Sedangkan dari kelompok keterampilan berbahasa secaratulis, meliputi membaca dan menulis. Jika dilihat dari sifatnya, keterampilan berbahasa secara lisan bersifat reseptif, yakni menerima atau memahami pesan yang disampaikan oleh pembicaraa atau penulis. Sedangkan keterampilan berbahasa secara tulis bersifat produktif, yakni menghasilkan pembicaraan dan atau tulisan. Dalam keterampilan satu ini, berbeda dengan kegiatan mendengarkan (Tarigan, 1980). 
Model Pembelajaran Cooperative Integrated Reading and Composition CIRC (Kooperatif Terpadu Membaca dan Menulis). Terjemahan bebas dari CIRC adalah komposisi terpadu membaca dan menulis secara koperatif-kelompok. Model pembelajaran Cooperative Integrated Reading and Composition-CIRC (Kooperatif Terpadu Membaca dan Menulis) merupakan model pembelajaran khusus Mata pelajaran Bahasa Indonesia dalam rangka membaca dan menyimpulkan teks bacaan, Model pembelajaran Cooperative Integrated Reading and Composition (CIRC) ini dapat dikategorikan pembelajaran terpadu.

Menurut Fogarty (1991), berdasarkan sifat keterpaduannya, pembelajaran terpadu dapat dikelompokkan menjadi:

a. Model dalam satu disiplin ilmu yang meliput imodel connected (keterhubungan) dan model nested (terangkai);

b. Model antar bidang studi yang meliputi model sequenced (urutan), model shared (perpaduan), model webbed (jaring laba-laba), model theaded (bergalur) dan model integreted (terpadu);

c. Model dalam lintassiswa.

Dalam pembelajaran CIRC atau pembelajaran terpadu setiap siswa bertanggung jawab terhadap tugas kelompok. Setiap anggota kelompok saling mengeluarkan ide-ide untuk memahami suatu konsep dan menyelesaikan tugas (task), sehingga terbentuk pemahaman yang dan pengalaman belajar yang lama. Model pembelajaran ini terus mengalami perkembangan mulai dari tingkat Sekolah Dasar (SD) hingga sekolah menengah. Proses pembelajaran ini mendidik siswa berinteraksi sosial dengan lingkungan. Prinsip belajar terpadu ini sejalan dengan empat pilar pendidikan yang digariskan UNESCO dalam kegiatan pembelajaran. Empat pilar itu adalah "belajar untuk mengetahui (learning to know), belajar untuk berbuat (learning to do), belajar untuk menjadi diri sendiri (learning to be), dan belajar hidup dalam kebersamaan (Learning to IVe together), (Depdiknas, 2002).

\section{METODE}

Penelitian ini adalah penelitian tindakan kelas (Classroom Action Research) dengan menerapkan model pembelajaran Cooperative Integreted Reading and Composition(CIRC). Menurut Zainal Aqib dkk, merumuskan langkah-langakah PTK ada empat tahab yaitu perencanaan, pelaksanaan, pengamatan dan refleksi. Analisis penelitian ini adalah analisis deskriptif kuantitatif dan kualitatif dimana dalam penelitian ini selain penyajian hasil berupa data maupun angka juga observasi. Penelitian ini dilaksanakan pada kelas I SD Negeri kalirejo 03 tahun pelajaran 2020/2021 selama II siklus secara luring, siklus I dilaksanakan pada tanggal 16 November 2020 dan siklus II dilaksanakan pada tanggal 23 November 2020 , dimana pengumpulan data dilakukan dengan observasi dan tes. Untuk mengetahui keberhasilan belajar yaitu dari Observasi yang di peroleh dari sikap dan ketrampilan, sedangkan tes secara tertulis dari LKPD dan tes formatif.

\section{HASIL DAN PEMBAHASAN}

Pada siklus I pembelajaran dilaksanakan dalam satu pertemuan dengan diadakan pos tes untuk mengetahui keberhasilan dalam pembelajaran. Siklus I ini membahas tentang materi kosa kata dalam pembelajaran model CIRC atau pembelajaran terpadu setiap siswa bertanggungjawab terhadap tugas kelompok, setiap anggota kelompok saling mengeluarkan ide ide untuk memahami suatu konsep. Sehingga terbentuk pemahaman yang baru. Langkah langkah pembelajaran model CIRC : membentuk kelompok yang aggotanya 3 orang siswa secara heterogen, guru memberikan wacana sesuai dengan topik pembelajaran, siswa 
bekerja sama saling membacakan dan menyimpulkan teks bacaan dan ditulis pada lembar kertas, mempresentasikan atau membacakan hasil kelompok. Dari kegiatan tersebut bisa dilihat dengan tabel sebagai berikut:

Tabel1. Perbandingan Antar Siklus

\begin{tabular}{lcccc}
\hline \multicolumn{1}{c}{ Aspek } & Pra siklus & $\begin{array}{c}\text { Persen } \\
(\%)\end{array}$ & $\begin{array}{c}\text { Siklus } \\
\text { I }\end{array}$ & $\begin{array}{c}\text { Persen } \\
(\%)\end{array}$ \\
\hline Nilai terendah & 40 & & 40 & \\
\hline Nilai tertinggi & 90 & & 90 & \\
\hline Jumlah siswa tuntas & 3 & $30 \%$ & 6 & $60 \%$ \\
\hline Jumlah siswa tidak tuntas & 7 & $70 \%$ & 4 & $40 \%$ \\
\hline Rata rata kelas & 58 & & 62 & \\
\hline
\end{tabular}

Berdasarkan tabel diatas terjadi peningkatan, pada pra siklus yang tuntas 3 siswa dari 10 siswa sedang pada siklus 1 meningkat yang tuntas dari 3 siswa menjadi 6 siswa, dengan demikian presentase klasikal yang mencapai KKM menjadi $60 \%$.

Berdasarkan refleksi pada siklus I maka diputuskan untuk melanjutkan ke siklus 2 dikarenakan belum mencapai ketuntasan klasikal yang diharapkan. Siklus 2 ini masih membahas tentang materi kosa kata dengan model pembelajaran CIRC dengan hasil belajar peserta didik pada siklus 2 yang bisa diihat pada tabel berikut:

Tabel 2. Hasil Siklus II

\begin{tabular}{lcc}
\hline \multicolumn{1}{c}{ Aspek } & $\begin{array}{c}\text { Siklus } \\
\text { II }\end{array}$ & $\begin{array}{c}\text { Persen } \\
(\%)\end{array}$ \\
\hline Nilai terendah & 60 & \\
\hline Nilai tertinggi & 100 & \\
\hline Jumlah siswa tuntas & 9 & $90 \%$ \\
\hline Jumlah siswa tidak tuntas & 1 & $10 \%$ \\
\hline Rata rata kelas & 86 & \\
\hline
\end{tabular}

Ketuntasan klasikal mengalami peningkatan dari jumlah siswa 10 yang tuntas atau mencapai KKM pada siklus 2 ini 9 siswa sedang yang tidak tuntas KKM mengalami penurunan yaitu 1 siswa sehigga presentase ketuntasan klasikal meningkat dari $60 \%$ menjadi 90\% dengan demikian dari ke 2 siklus dengan menggunakan model CIRC dapat meningkatkan hasil peserta didik pada Mupel bahasa indonesia kelas I di SDN Kalirejo 03. Kelebihan dari model pembelajaran terpadu atau (CIRC) antara lain:

1) Pengalaman dan kegiatan belajar anak didik akan selalu relevan dengan tingkat perkembangan anak;

2) Kegiatan yang dipilih sesuai dengan dan bertolak dari minat siswa dan kebutuhan anak;

3) Seluruh kegiatan belajar lebih bermakna bagi anak didik sehingga hasil belajar anak didik akan dapat bertahan lebih lama;

4) Pembelajaran terpadu dapat menumbuh-kembangkan keterampilan berpikir anak

5) Pembelajaran terpadu menyajikan kegiatan yang bersifat pragmatis (bermanfaat) sesuai dengan permasalahan yang sering ditemuai dalam lingkungan anak;

6) Pembelajaran terpadu dapat menumbuhkan motivasi belajar siswa kearah belajar yang dinamis, optimal dan tepatguna;

7) Menumbuh kembangkaninteraksi sosial anak seperti kerja sama, toleransi, komunikasi dan respek terhadap gagasan orang lain;

8) Membangkitkan motivasi belajar, memperluas wawasan dan aspirasi guru dalam mengajar (Saifulloh,2003). 


\section{SIMPULAN}

Penerapan model pembelajaran Cooperative Integretad Reading and Composition (CIRC) dapat meningkatkan hasil pembelajaran peserta didik kelas I Mupel bahasa Indonesia pada materi kosa kata. peningkatan yang terjadi karena adanya kesan pembelajaran yang mendalam dari peserta didik terhadap materi yang diajarkan melalui pembelajaran yang menyenangkan dengan bekerja sama dengan teman. Peserta didik akan selalu teringat akan materi yang diajarkan dikarenakan mereka menemukan dan membangun sendiri pengetahuan mereka pada saat menyelesaikan permasalahan. berdasarkan penelitian yang telah dilaksanakan salah satu model pembelajaran yang harus dikuasai oleh Guru adalah Cooperative Integretad Reading and Composition (CIRC) karena model ini sangat cocok digunakan pada muatan pelajaran Bahasa Indonesia Peserta didik akan membangun pengetahuannya sendiri dengan berdiskusi , Guru bisa memantau proses selama berdiskusi dilaksanakan dengan bekerja sama denga teman teman.

\section{DAFTAR PUSTAKA}

Arikunto, dkk. 2011. Penelitian Tindakan Kelas. Jakarta: Bumi Aksara.

Alfiroh, Nia,Fogarty "Penerapan Pembelajaran Kooperatif Tipe CIRC (Cooperative Integrated Reading And Composition)

Kemendikbud. (2013).Permedikbud Nomor 65 Tahun 2013 Tentang Standar proses 